\title{
Effects of experimental warming on soil respiration and biomass in Quercus variabilis Blume and Pinus densiflora Sieb. et Zucc. seedlings
}

\author{
Nam Jin Noh ${ }^{1}$ - Sun Jeong Lee ${ }^{2}$ Wooyong $\mathrm{Jo}^{3}$ • Saerom Han ${ }^{3}$ - Tae Kyung Yoon ${ }^{4}$. \\ Haegeun Chung ${ }^{5} \cdot$ Hiroyuki Muraoka ${ }^{1}$ • Yowhan Son ${ }^{3,6}$
}

Received: 11 August 2015 /Accepted: 14 March 2016/Published online: 24 March 2016

(C) INRA and Springer-Verlag France 2016

\begin{abstract}
- Key message In the open-field warming experiment using infrared heaters, $3{ }^{\circ} \mathrm{C}$ warming affected soil respiration more in the deciduous Quercus variabilis Blume plot than in the evergreen Pinus densiflora Sieb. et Zucc. plot, but did not affect the plant biomass in either species.

- Context Understanding the species-specific responses of belowground carbon processes to warming is essential for the accurate prediction of forest carbon cycles in ecosystems affected by future climate change.
\end{abstract}

Handling Editor: Thomas Wohlgemuth

Contribution of the co-authors Nam Jin Noh: experimental design, fieldwork, data analysis and writing the paper; Sun Jeong Lee and Wooyong Jo: fieldwork, biomass data analysis and site management; Saerom Han: meteorological data analysis; Tae Kyung Yoon, Haegeun Chung and Hiroyuki Muraoka: writing the paper; Yowhan Son: research project coordination and writing the paper

Yowhan Son

yson@korea.ac.kr

Nam Jin Noh

treeworld@green.gifu-u.ac.jp

Sun Jeong Lee

sunjleei@gmail.com

Wooyong Jo

radiojwy@hanmail.net

Saerom Han

saerom.han@gmail.com

Tae Kyung Yoon

yoon.ecology@gmail.com

Haegeun Chung

hchung@konkuk.ac.kr
- Aims This study aimed to investigate the effect of experimental warming on soil $\mathrm{CO}_{2}$ efflux, soil-air $\mathrm{CO}_{2}$ concentration, and plant biomass for two taxonomically different temperate tree species.

- Methods Experimental warming was conducted in an openfield planted with $Q$. variabilis and $P$. densiflora seedlings. Infrared heaters increased the air temperature by $3{ }^{\circ} \mathrm{C}$ in the warmed plots compared with the air temperature in the control plots over a 2-year period.

- Results The increase in air and soil temperature stimulated soil $\mathrm{CO}_{2}$ efflux by 29 and $22 \%$ for the $Q$. variabilis and $P$. densiflora plots, respectively. Seasonal variation in the warming effect on soil $\mathrm{CO}_{2}$ efflux was species-specific. Soil $\mathrm{CO}_{2}$ efflux was also positively related to both soil temperature and soil water content. The soil moisture deficit decreased the difference in soil $\mathrm{CO}_{2}$ efflux between the control and warmed plots. Warming did not affect soil $\mathrm{CO}_{2}$ concentration and plant biomass in either species; however, the mean soil $\mathrm{CO}_{2}$ con-

Hiroyuki Muraoka

muraoka@green.gifu-u.ac.jp

River Basin Research Center, Gifu University, Gifu 501-1193, Japan

2 Forest and Climate Change Center, Korea Forest Research Institute, Seoul 130-712, Republic of Korea

3 Department of Environmental Science and Ecological Engineering, Korea University, Seoul 136-713, Republic of Korea

4 Department of Environmental Science and Engineering, Ewha Womans University, Seoul 120-750, Republic of Korea

5 Department of Environmental Engineering, Konkuk University, Seoul 143-701, Republic of Korea

6 Department of Biological and Environmental Sciences, Qatar University, Doha 2713, Qatar 
centration was positively correlated with root and total biomass.

- Conclusion Warming increased soil $\mathrm{CO}_{2}$ efflux in both $Q$. variabilis and $P$. densiflora plots, while the increase showed remarkable seasonal variations and different magnitudes for the two species.

Keywords Climate change $\cdot$ Experimentalwarming $\cdot$ Oriental oak $\cdot$ Red pine $\cdot$ Soil respiration

\section{Introduction}

Ongoing climate warming is expected to have a considerable impact on terrestrial carbon (C) dynamics by altering ecosystem functions and processes (IPCC 2013; Khaine and Woo 2015; Lu et al. 2013; Spittlehouse and Stewart 2003). To understand possible changes in the eco-physiological traits and biogeochemical properties of forest ecosystems, a growing number of warming manipulation studies have been conducted using tree seedlings (Chung et al. 2013; Fisichelli et al. 2014). Previous warming studies have suggested that elevated temperatures stimulate tree growth and photosynthesis, and extend the growing season of coniferous (Xu et al. 2012; Yin et al. 2008) and deciduous tree seedlings (e.g., Danyagri and Dang 2014; Kaye and Wagner 2014; Morin et al. 2010). However, the magnitude of these warming effects may differ according to plant functional group and biome (Lin et al. 2010; Way and Oren 2010). Fisichelli et al. (2014) recently reported the species-specific responses (e.g., emergence, leafout rate, and growth) of 15 North American tree species to climate change, identifying marked differences between the broadleaf temperate and coniferous groups.

Variation in the response of belowground components (e.g., soil and root respiration, root exudates, and microbial processes) to experimental warming can provide key information on the carbon transition from leaf photosynthesis to soil during rises in temperature (Atkin et al. 2000; Bradford et al. 2008; Liu et al. 2011; Yin et al. 2013). For example, a few recent studies have reported warming-induced soil respiration in silver birch, Norway spruce, and Scots pine seedlings growing in similar boreal ecosystems (Pumpanen et al. 2012), and in a dragon spruce plantation and natural forests (Xu et al. 2012; Yin et al. 2013). Soil respiration $\left(R_{\mathrm{S}}\right.$, soil $\mathrm{CO}_{2}$ efflux $)$ is an important natural source of $\mathrm{CO}_{2}$ atmospheric emissions, as well as a representative indicator of soil biological activity (Schlesinger and Andrews 2000). Soil-air $\mathrm{CO}_{2}$ concentration $\left(\mathrm{SCO}_{2}\right)$ determines the amount of $\mathrm{CO}_{2}$ available for efflux from the soil to the atmosphere (Maier and Schack-Kirchner 2014). Because $R_{\mathrm{S}}$ and rhizosphere $\mathrm{SCO}_{2}$ strongly depend on the photosynthetic activity of plants supplying carbohydrates from leaves to the roots and rhizosphere (Kuzyakov and Gavrichkova 2010), variation in forest canopy processes (e.g., leaf phenology, plant growth and photosynthesis rates) is likely to influence belowground $\mathrm{C}$ dynamics (Inoue et al. 2012; Moyano et al. 2008). Therefore, the synthetic analysis of the responses of these parameters to warming can provide useful field evidence of the relationship between aboveground and belowground $\mathrm{C}$ processes (Flanagan et al. 2013; Li et al. 2011). In addition, detailed information about temporal variation in the effect of warming on $R_{\mathrm{S}}$ may aid in the understanding of responses among species with different leaf phenology (Contosta et al. 2011). However, few studies have investigated the seasonal impact of climate warming on $R_{\mathrm{S}}$ in two taxonomically different tree species.

The potential impact of climate change on the distribution of broad-leaved and coniferous tree species in the boreal zone were analyzed using observation and modeling in Northern Europe (Sykes and Prentice 1996) and British Columbia (Hamann and Wang 2006). Pinus densiflora Zieb. et Zucc. and Quercus species, which together occupy about $50 \%$ of forest area in South Korea, are representative temperate coniferous and broad-leaved trees species, respectively (Korea Forest Service 2014). Based on future climate projections, tree growth models have predicted that $P$. densiflora forests in South Korea will gradually be replaced by Quercus forests (Byun et al. 2013; Kwak et al. 2012). However, the prediction should be validated with field evidence from artificial manipulation experiments (Rustad 2008). Our previous studies have demonstrated that artificial warming increases photosynthetic rates and the growing periods of Quercus variabilis Blume seedlings (Han et al. 2014a; Jo et al. 2011; Lee et al. 2012), while warming increases the leaf biomass and nitrogen content of $P$. densiflora seedlings (Lee et al. 2013). However, the species-specific responses of belowground $\mathrm{C}$ processes to warming remain unclear.

In this study, we examined the effects of warming on $R_{\mathrm{S}}$, $\mathrm{SCO}_{2}$, and plant biomass for seedlings of the deciduous $Q$. variabilis and the evergreen $P$. densiflora trees using infrared heaters. The study aimed to address the following questions: (1) How do $R_{\mathrm{S}}, \mathrm{SCO}_{2}$, and plant biomass for $Q$. variabilis and $P$. densiflora respond to warming? and (2) Is there seasonal variation in the magnitude of the warming effects? Generally, deciduous tree species are more sensitive to elevated temperatures than are evergreen trees (Way and Oren 2010). Therefore, we hypothesized that the $R_{\mathrm{S}}$ and $\mathrm{SCO}_{2}$ responses in $Q$. variabilis seedlings to a rise in temperature would be more pronounced than in $P$. densiflora seedlings. These results will be useful for predicting species composition and $\mathrm{C}$ cycling in the face of future climate warming.

\section{Materials and methods}

\subsection{Experimental design}

This study was conducted at an experimental tree nursery (Fig. 1a) located in the Korea University Arboretum, Seoul, 
Fig. 1 Appearance of a the experimental warming study site using $\mathbf{b}$ infrared heaters in an open-field planted with $Q$. variabilis $(Q)$ and $P$. densiflora $(P)$ seedlings, and $\mathbf{c}$ the experimental design. In April 2010, a total of 16 experimental plots $(1 \times 1 \mathrm{~m}$ with a 2 -m buffer between the plots) were established. The soil temperature at a depth of $5 \mathrm{~cm}$ and the volumetric soil moisture content at depths from 0 to $10 \mathrm{~cm}$ were monitored in the center of each experimental plot using soil temperature sensors (108-LC, Campbell Inc., USA) and soil moisture sensors (CS616, Campbell Inc., USA) $(n=16)$, respectively

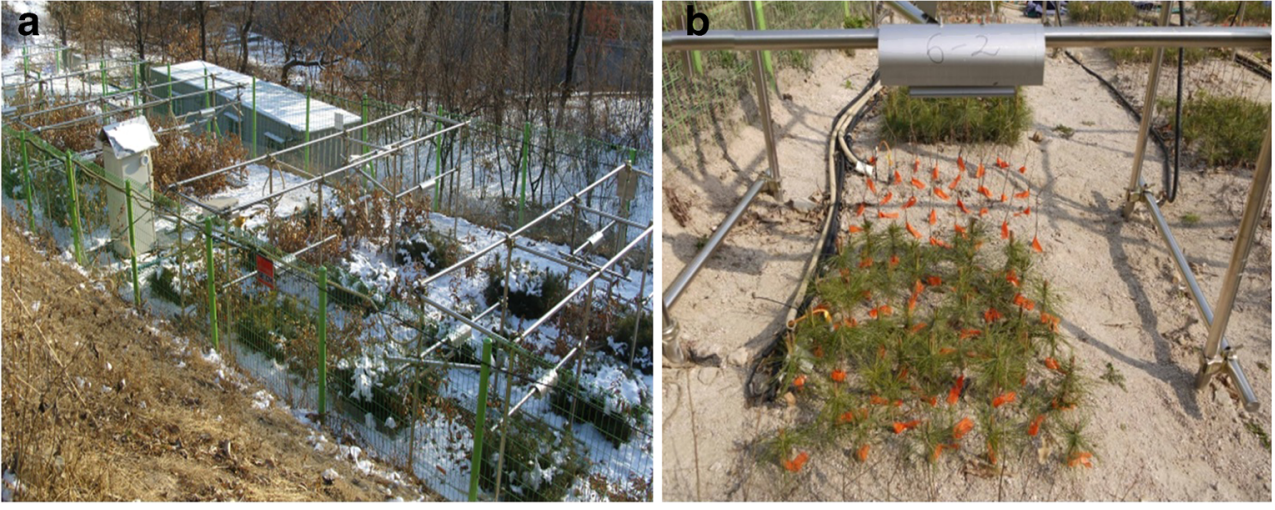

C

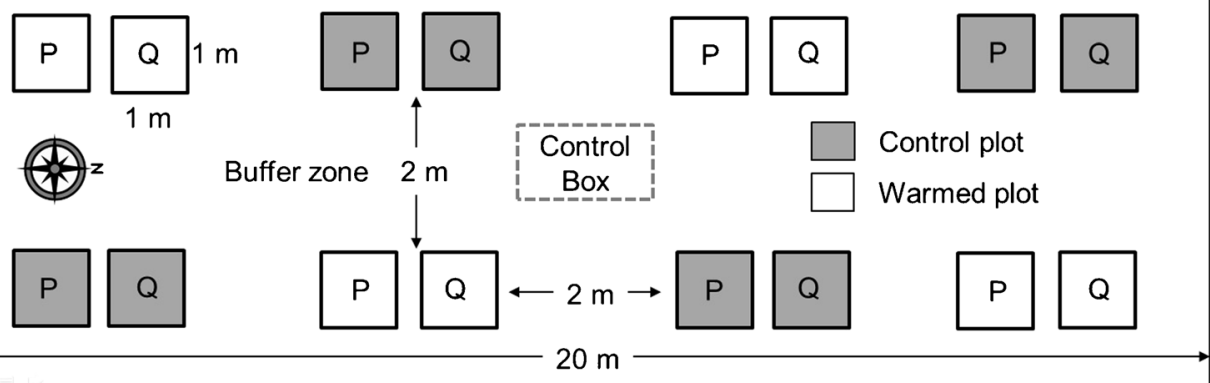

Korea $\left(37^{\circ} 35^{\prime} 36^{\prime \prime} \mathrm{N}, 127^{\circ} 1^{\prime} 31^{\prime \prime} \mathrm{E}\right)$. The annual mean air temperature and precipitation of the area are $12.5^{\circ} \mathrm{C}$ and $1450.5 \mathrm{~mm}$, respectively (1981-2010) (Korea Meteorological Administration 2015). In April 2010, a total of 16 experimental plots $(1 \times 1 \mathrm{~m}$ with a 2 -m buffer between the plots) were established for the $Q$. variabilis Blume and P. densiflora Sieb. et Zucc. seedlings (Fig. 1c).

Soil and seedbed conditions were based on the open-field conditions at Korea University Arboretum. The mineral soil was collected from the forest close to campus of Korea University where the bedrock is characterized by granitic parent rock materials. After collection, the soil was sieved to remove coarse rocks. The soil is classified into sandy soil with a $\mathrm{pH}$ of 6.85 and a cation exchange capacity of $5.12 \mathrm{cmol} \mathrm{kg}^{-1}$. Total $\mathrm{C}$ and $\mathrm{N}$ concentrations were 2.18 and $0.16 \mathrm{mg} \mathrm{kg}^{-1}$, respectively (Jo et al. 2011). The tree species were $Q$. variabilis (Oriental oak), a deciduous broad-leaved tree, and $P$. densiflora (Japanese red pine), a coniferous tree. In May 2010, sixty-four 1-year-old Q. variabilis and ninety 1year-old $P$. densiflora seedlings of similar sizes (i.e., of similar heights and root collar diameters) were planted in each plot (Lee et al. 2009). Subsequent thinning in March 2011 resulted in 35 Q variabilis seedlings and 45 P. densiflora seedlings per plot (Fig. 1b). Open-field warming systems were set up in November 2010, consisting of eight infrared heaters (FTE1000; Mor Electric Heating Instrument Inc., USA) in the warmed plots and eight dummy heaters of the same size and shape in the eight control plots. Each treatment (i.e., the control and warmed treatments for $Q$. variabilis [CQ and WQ] and the control and warmed treatments for P. densiflora $[\mathrm{CP}$ and WP]) had four replications. The heaters were deployed at a height of about $60 \mathrm{~cm}$ above the seedling canopy at the center of each plot as it had been done in the study of Kimball et al. (2008). The warming system was designed to automatically maintain air temperature $3{ }^{\circ} \mathrm{C}$ warmer than the control plots by using the infrared heaters. The temperature differential was chosen according to IPCC SRES climate change scenario model predictions for the projected $3.26{ }^{\circ} \mathrm{C}$ increase in air temperature in South Korea by the year 2061 to 2070 compared to the mean value between 2001 and 2010 (KMA 2012). The differences in air temperature between the control and warmed plots for $Q$. variabilis were monitored using one infrared temperature sensors per plot (SI-111, Campbell Inc., USA) $(n=4)$. We assumed that, after accounting for the heat diffusion of air in an open-field system, for each $Q$. variabilis and $P$. densiflora plot pair, the air temperatures were homogeneous due to the equal distances between the seedling canopy surface and the infrared heater. The soil temperature at a depth of $5 \mathrm{~cm}$ and the volumetric soil moisture content at depths from 0 to $10 \mathrm{~cm}$ were measured in the center of each experimental plot using soil temperature sensors (108-LC, Campbell Inc., USA) and soil moisture sensors (CS616, Campbell Inc., USA) $(n=16)$, respectively. All data were recorded using data loggers (CR-3000, Campbell Inc., USA).

\subsection{Measurements of soil $\mathrm{CO}_{2}$ efflux and concentration}

Soil $\mathrm{CO}_{2}$ efflux $\left(R_{\mathrm{S}}\right)$ was measured using a closed chamber system with a portable diffusion-type non-dispersive infrared 
(NDIR) $\mathrm{CO}_{2}$ sensor (GMP343, Vaisala CARBOCAP, Finland), which has high selectively and sensitivity in openair conditions (Yasuda et al. 2012), and a small chamber made of polyacrylics. The sensors were well calibrated at least once a year with standard $\mathrm{CO}_{2}$ gases. The size of the chamber $(10 \mathrm{~cm}$ in diameter, $12 \mathrm{~cm}$ in height) was designed so that it could be placed among high-density seedlings and allow the repetitive testing of linear changes in $\mathrm{CO}_{2}$ inside the chamber. The chamber size was sufficiently small that it did not require an internal fan to ensure the mixing of gases. The sharp-edged chamber was directly inserted into the soil using clearly marked $2 \mathrm{~cm}$-deep slits. A handheld control and logger (MI70, Vaisala CARBOCAP, Finland) coupled with the NDIR $\mathrm{CO}_{2}$ sensor recorded the $\mathrm{CO}_{2}$ concentration every $5 \mathrm{~s}$ during a 300-s measurement period (Bekku et al. 1995). The first $30 \mathrm{~s}$ of data after the placement of the chamber were excluded from the subsequent analysis to allow for the initial adjustment of $\mathrm{CO}_{2} \cdot R_{\mathrm{S}}$ was calculated from the following formula

$R_{\mathrm{S}}=\frac{d \mathrm{CO}_{2}}{d t} \times \frac{P V}{A R T}$

where $P$ is the atmospheric pressure, $V$ is the volume of the headspace gas within the chamber, $A$ is the soil surface area enclosed by the chamber, $R$ is the gas constant, and $T$ is the air temperature $(K)$ (Davidson et al. 1998). $R_{\mathrm{S}}$ measurements $(n=4)$ were made between 10:00 and 14:00 monthly from June 2011 to April 2012.

Rhizosphere soil-air $\mathrm{CO}_{2}$ concentration $\left(\mathrm{SCO}_{2}, \mu \mathrm{mol} \mathrm{mol}^{-1}\right)$ was monitored continuously at 1-h intervals using 16 NDIR $\mathrm{CO}_{2}$ sensors (GMT222, Vaisala CARBOCAP, Finland) with a CR-3000 data logger from 2011 to 2012. One solid-state $\mathrm{CO}_{2}$ sensor per plot was inserted vertically into centrally located holes pre-drilled to a $5-\mathrm{cm}$ soil depth by an auger. An occasional malfunction of the data logging system in the summer resulted in some missing $\mathrm{SCO}_{2}$ data. The missing data was $36 \%$ in 2011 and $19 \%$ in 2012.

\subsection{Plant biomass}

To measure the root and shoot biomass of the $Q$. variabilis and $P$. densiflora seedlings, the seedlings were excavated by carefully pulling them up while minimizing disturbance to the soil systems. The excavation of intact roots was generally easy because the root systems of the young seedlings grown in the sandy soil were small. However, since some of the more elongated roots of $Q$. variabilis seedlings were broken during excavation, ten seedlings without any damage were sampled per plot in March 2012, followed by five seedlings per plot in March 2013. The samples were separated into shoot and root components after washing. The soil-free samples were ovendried at $65^{\circ} \mathrm{C}$ to a constant weight. The biomass $\left(\mathrm{kg} \mathrm{m}^{-2}\right)$ was calculated by the mean dry weight per seedling $\left(\mathrm{g} \mathrm{tree}^{-1}\right)$ and the number of seedlings in the plots (tree $\mathrm{m}^{-2}$ ).

\subsection{Statistical analysis}

A three-way analysis of variance (ANOVA) was used to examine the effects of experimental warming, species, year, and their interaction on soil temperature, water content, plant biomass, $\mathrm{SCO}_{2}$, and $R_{\mathrm{S}}$. A two-way ANOVA was used to analyze the effects of species and month on the response of $R_{\mathrm{S}}$ to warming. In order to assess the warming effect, we used the differences in measurements between the control and warmed plots and the response ratio of $R_{\mathrm{S}}$ to warming. The response ratio was defined as the percentage increase ratio $(\%)=\left(R_{\mathrm{S}}\right.$ warmed $\left./ R_{\mathrm{S} \text { control }}-1\right) \times 100$, where a negative value indicates a negative effect. To correct for differences caused by uneven soil temperature increases across the different species or different months, we normalized the warming effect to provide a value per $1{ }^{\circ} \mathrm{C}$ increase by dividing the response ratio by the actual temperature increase. To measure the sensitivity of $R_{\mathrm{S}}$ to seasonal temperature, we used the exponential function $R_{\mathrm{S}}=a \exp ^{b T}$, where $R_{\mathrm{S}}$ is soil respiration, $T$ is soil temperature, and the coefficient $a$ is the intercept of soil respiration when the temperature is zero. The coefficient $b$ is used to calculate the Van't Hoff's temperature coefficient $\left(Q_{10}=\exp ^{10 b}\right)$, which expresses the increase in $R_{\mathrm{S}}$ with a $10{ }^{\circ} \mathrm{C}$ increase in temperature during measurement (Curiel Yuste et al. 2004). Linear regression analysis was used to examine the relationships between soil water content vs. $R_{\mathrm{S}}$ and soil water content vs. the warming effect on $R_{\mathrm{S}}$. Tukey's studentized range test or Student's $t$ tests were used to analyze the differences in the $\mathrm{SCO}_{2}, R_{\mathrm{S}}$, and $Q_{10}$ among treatment plots. All significance levels were quoted at a $95 \%$ confidence level $(P<0.05)$. All statistical analyses were performed using SAS 9.4 (SAS Institute Inc., USA).

\section{Results}

\subsection{Soil temperature and soil water content}

The experimental open-field warming system significantly increased both air and soil temperatures (Table 1). Warming increased the annual mean air temperature by $2.5^{\circ} \mathrm{C}$ in 2011 and by $2.0^{\circ} \mathrm{C}$ in 2012 . The actual degree of warming was lower than the target air temperature increase of $3{ }^{\circ} \mathrm{C}$, and this discrepancy can be explained by the weather conditions and the seedling canopies. Warming increased the annual mean soil temperature by 1.1 and $1.3{ }^{\circ} \mathrm{C}$ at the $Q$. variabilis plot and by 2.4 and $1.5^{\circ} \mathrm{C}$ at the $P$. densiflora plot in 2011 and 2012, respectively $(P<0.001$; Table 2 , Fig. 2a, b). Some interactions among warming treatment, species, and year were also significant for soil temperature. In comparison to the 
Table 1 Results of a three-way ANOVA showing the $P$ values for the response of soil temperature $\left(T_{\mathrm{S}}\right)$, soil water content $(S W C)$, root and shoot biomass, $\mathrm{SCO}_{2}$, and $R_{\mathrm{S}}$ to species type, warming, and their interaction

\begin{tabular}{lclllll}
\hline Factor & $T_{\mathrm{S}}$ & $\mathrm{SWC}$ & Root & Shoot & $\mathrm{SCO}_{2}$ & $R_{\mathrm{S}}$ \\
\hline Warming (W) & $<0.0001^{* * *}$ & $0.0328^{*}$ & 0.5913 & 0.5648 & 0.7680 & $<0.0001^{* * *}$ \\
Species (S) & $0.0153^{* *}$ & $0.0021^{* *}$ & $<0.0001^{* * *}$ & $0.0070^{* *}$ & $0.0078^{* *}$ & $<0.0001^{* * *}$ \\
Year (Y) & $<0.0001^{* * *}$ & 0.6748 & $<0.0001^{* * *}$ & $0.0004^{* * *}$ & $0.0452^{*}$ & - \\
$\mathrm{W} \times \mathrm{S}$ & $0.0075^{* *}$ & 0.2906 & 0.2801 & 0.4939 & 0.5395 & $0.0098^{* *}$ \\
$\mathrm{~W} \times \mathrm{Y}$ & 0.1442 & 0.9299 & 0.7701 & 0.6665 & 0.8498 & - \\
$\mathrm{S} \times \mathrm{Y}$ & $0.0248^{*}$ & 0.8927 & $0.0005^{* * *}$ & $0.0287^{*}$ & 0.0849 & - \\
$\mathrm{S} \times \mathrm{W} \times \mathrm{Y}$ & $0.0498^{*}$ & 0.9133 & 0.8562 & 0.6306 & 0.8810 & - \\
\hline
\end{tabular}

$* P<0.05 ; * * P<0.01 ; * * * P<0.001$ consistent differences in air temperature between the control and warmed plots, the warming effects on soil temperature fluctuated with season due to the interception of infrared heat by broad leaves of $Q$. variabilis or needle foliage of $P$. densiflora. This shield effect on soil temperature was higher at the $Q$. variabilis plot than at the $P$. densiflora plot (Table 2).

Although warming significantly affected soil water content (Table 1), the annual mean soil water content did not significantly differ between the control and warmed plots of either species in either year (Table 2). Warming slightly decreased mean soil water content during all days without precipitation in all plots $(8.2 \mathrm{vol} \%$ in the control plots and $7.2 \mathrm{vol} \%$ in the warmed plots at the $Q$. variabilis plot, versus $6.6 \mathrm{vol} \%$ in the control plots and $5.5 \mathrm{vol} \%$ in the warmed plots at the P. densiflora plot; Table 2). The decrease in soil water content was less pronounced at the $Q$. variabilis plot (12\%) than the P. densiflora plot (17\%). These differences may be attributed to the differences in soil temperature or transpiration. In

Table 2 Annual mean air and soil temperature, soil water content, soil $\mathrm{CO}_{2}$ efflux $\left(R_{\mathrm{S}}\right)$ and concentration $\left(\mathrm{SCO}_{2}\right)$, and plant biomass (shoot and root) in the control and warmed plots planted with $Q$. variabilis and addition, soil water content was directly influenced by rainfall events (Fig. 2c).

Figure 3a shows the seasonal variation in actual warming effect on air temperature around the canopy surface, on soil temperature, and on soil water content. The differences in soil temperature were lower than those of air temperature for both species. However, there was less difference in the leaf expansion period and winter than in the leaf maturity period, and the increase in soil temperature was lower in the $Q$. variabilis plot than the P. densiflora plot.

\subsection{Response of $R_{\mathrm{S}}$ to warming}

Warming significantly affected $R_{\mathrm{S}}$ and there was also a significant interaction between warming and species type (Table 1). Warming significantly enhanced mean $R_{\mathrm{S}}$ by $29 \%$ at the $Q$. variabilis plot and by $22 \%$ at the $P$. densiflora plot (Table 2). During the 2011 measurements, the average $R_{\mathrm{S}}$ rate

P. densiflora seedlings in 2011 and 2012. The value represents the mean \pm 1 standard error $(n=4)$

\begin{tabular}{|c|c|c|c|c|c|c|c|c|c|}
\hline \multirow[t]{2}{*}{ Year } & \multirow[t]{2}{*}{ Variables } & \multicolumn{4}{|l|}{ Q. variabilis } & \multicolumn{4}{|l|}{ P. densiflora } \\
\hline & & Control & Warmed & $\mathrm{W}-\mathrm{C}\left(\%^{\mathrm{a}}\right)$ & $P$ value & Control & Warmed & $\mathrm{W}-\mathrm{C}(\%)$ & $P$ value \\
\hline \multirow[t]{9}{*}{2011} & Air temperature $\left({ }^{\circ} \mathrm{C}\right)$ & $12.4 \pm 0.2$ & $14.9 \pm 0.6$ & $+2.5(+20)$ & $<0.0001^{* * *}$ & - & - & - & - \\
\hline & Soil temperature $\left({ }^{\circ} \mathrm{C}\right)$ & $14.4 \pm 0.1$ & $15.5 \pm 0.3$ & $+1.1(7)$ & $0.0071^{* * *}$ & $14.4 \pm 0.1$ & $16.8 \pm 0.2$ & $+2.4(+17)$ & $<0.0001^{* * *}$ \\
\hline & Soil water content (\%) & $9.0 \pm 0.8$ & $8.6 \pm 0.2$ & $-0.4(-4)$ & 0.6325 & $7.5 \pm 0.8$ & $7.1 \pm 0.3$ & $-0.4(-5)$ & 0.6267 \\
\hline & $R_{\mathrm{S}}\left(\mu \mathrm{mol} \mathrm{CO} \mathrm{m}^{-2} \mathrm{~s}^{-1}\right)$ & $3.38 \pm 0.27$ & $4.37 \pm 0.18$ & $+0.99(+29)$ & $0.0090^{* *}$ & $2.87 \pm 0.16$ & $3.50 \pm 0.15$ & $+0.63(+22)$ & $0.0105^{*}$ \\
\hline & Annual mean $\mathrm{SCO}_{2}\left(\mu \mathrm{mol} \mathrm{mol}^{-1}\right)$ & $3158 \pm 191$ & $3532 \pm 332$ & $+374(+12)$ & 0.3664 & $3061 \pm 333$ & $2977 \pm 236$ & $-84(-3)$ & 0.8437 \\
\hline & $\Delta \mathrm{SCO}_{2}(\mathrm{Nov}-\mathrm{Apr})$ & $1100 \pm 80$ & $1309 \pm 372$ & $+209(+19)$ & 0.6017 & $970 \pm 0.021$ & $931 \pm 189$ & $-39(-4)$ & 0.7005 \\
\hline & Shoot biomass $\left(\mathrm{kg} \mathrm{m}^{-2}\right)$ & $0.35 \pm 0.07$ & $0.49 \pm 0.14$ & $+0.14(+40)$ & 0.4125 & $0.27 \pm 0.02$ & $0.23 \pm 0.02$ & $-0.04(-15)$ & 0.2532 \\
\hline & Root biomass $\left(\mathrm{kg} \mathrm{m}^{-2}\right)$ & $1.02 \pm 0.15$ & $1.26 \pm 0.18$ & $+0.24(+24)$ & 0.3493 & $0.23 \pm 0.01$ & $0.19 \pm 0.01$ & $-0.04(-17)$ & 0.0595 \\
\hline & Shoot + root & $1.38 \pm 0.21$ & $1.75 \pm 0.32$ & $+0.37(+27)$ & 0.3669 & $0.50 \pm 0.02$ & $0.42 \pm 0.03$ & $-0.08(-16)$ & 0.0631 \\
\hline \multirow[t]{8}{*}{2012} & Air temperature $\left({ }^{\circ} \mathrm{C}\right)$ & $11.8 \pm 0.1$ & $13.8 \pm 0.1$ & $+2.0(+17)$ & $<0.0001^{* * *}$ & - & - & - & - \\
\hline & Soil temperature $\left({ }^{\circ} \mathrm{C}\right)$ & $12.7 \pm 0.1$ & $14.0 \pm 0.3$ & $+1.3(10)$ & $0.0035^{* *}$ & $12.6 \pm 0.2$ & $14.1 \pm 0.2$ & $+1.5(+12)$ & $0.0010^{* * * *}$ \\
\hline & Soil water content $(\%)$ & $7.5 \pm 0.4$ & $7.8 \pm 0.1$ & $-0.4(-4)$ & 0.1185 & $7.6 \pm 0.3$ & $6.8 \pm 0.4$ & $-0.4(-5)$ & 0.5534 \\
\hline & Annual mean $\mathrm{SCO}_{2}\left(\mu \mathrm{mol} \mathrm{mol}{ }^{-1}\right)$ & $4416 \pm 646$ & $4587 \pm 428$ & $+171(+4)$ & 0.8328 & $3166 \pm 407$ & $2977 \pm 236$ & $-189(-6)$ & 0.8822 \\
\hline & $\Delta \mathrm{SCO}_{2}(\mathrm{Nov}-\mathrm{Apr})$ & $1532 \pm 76$ & $1437 \pm 153$ & $-95(-6)$ & 0.6020 & $1181 \pm 73$ & $1193 \pm 169$ & $+12(+1)$ & 0.9502 \\
\hline & Shoot biomass $\left(\mathrm{kg} \mathrm{m}^{-2}\right)$ & $2.53 \pm 0.66$ & $3.41 \pm 1.42$ & $+0.88(+35)$ & 0.5996 & $1.29 \pm 0.08$ & $1.20 \pm 0.08$ & $-0.09(-7)$ & 0.4595 \\
\hline & Root biomass $\left(\mathrm{kg} \mathrm{m}^{-2}\right)$ & $4.82 \pm 1.07$ & $5.45 \pm 1.27$ & $+0.63(+13)$ & 0.7141 & $1.03 \pm 0.09$ & $1.12 \pm 0.05$ & $+0.09(+9)$ & 0.3842 \\
\hline & Shoot + root & $7.35 \pm 1.72$ & $8.86 \pm 2.65$ & $+1.33(+21)$ & 0.6499 & $2.19 \pm 0.15$ & $2.32 \pm 0.12$ & $+0.13(+6)$ & 0.9825 \\
\hline
\end{tabular}

$* P<0.05 ; * * P<0.01 ; * * * P<0.001$

${ }^{a}$ Percentage increase $(+)$ or decrease $(-)$ 


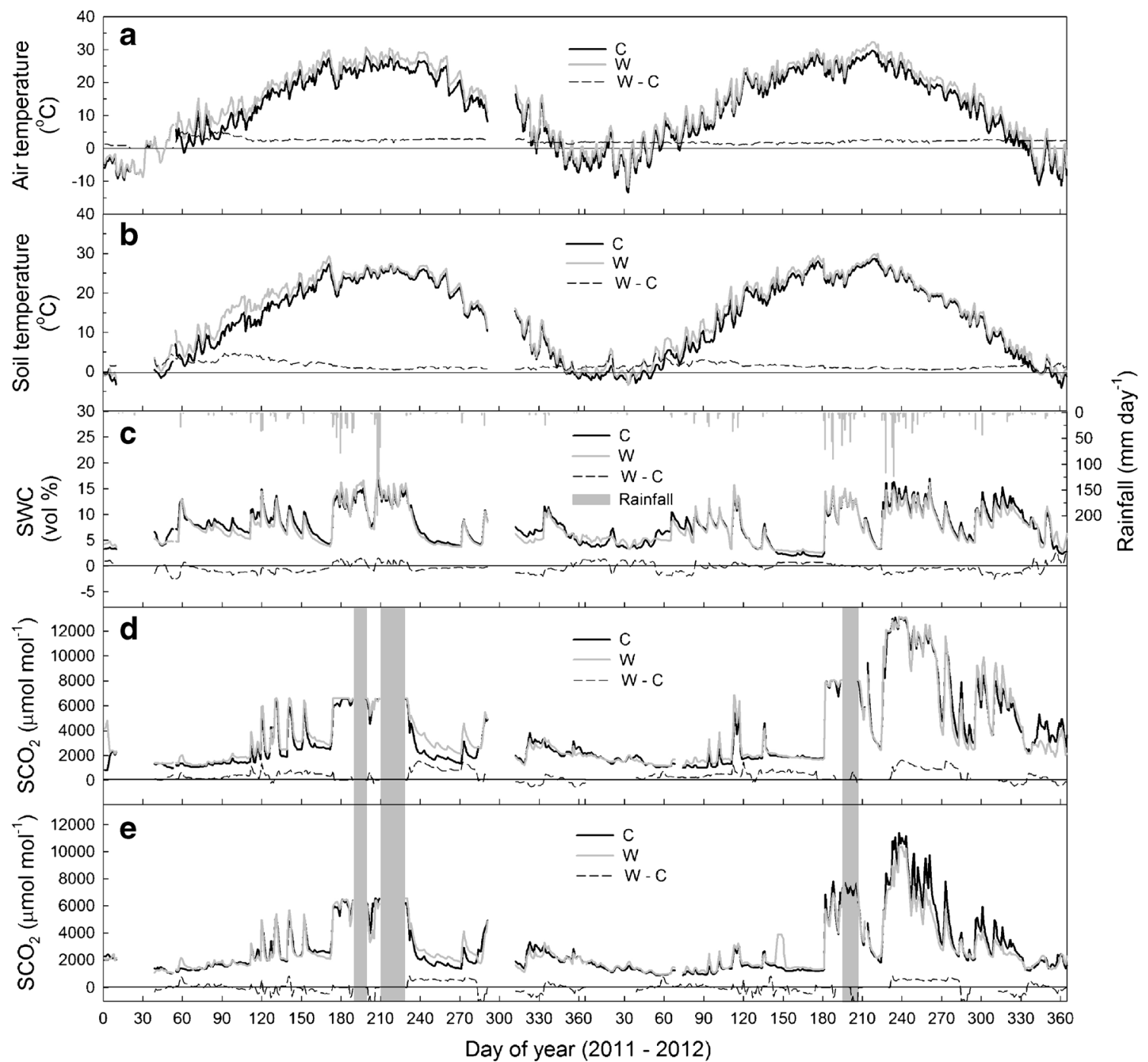

Fig. 2 Seasonal variations in the daily mean a air temperature $(n=4)$ at the $Q$. variabilis plots; $\mathbf{b}$ soil temperature $(n=8)$; $\mathbf{c}$ volumetric soil water content $(n=8)$ and rainfall at the all plots, and the seasonal variation in soil-air $\mathrm{CO}_{2}$ concentration $(n=4)$ at the $\mathbf{d} Q$. variabilis and $\mathbf{e} P$. densiflora

( $\mu \mathrm{mol} \mathrm{CO}_{2} \mathrm{~m}^{-2} \mathrm{~s}^{-1}$ ) was significantly higher in the warmed plots than in the control plots for both $Q$. variabilis $(3.38$ \pm 0.27 in the control plots and $4.37 \pm 0.18$ in the warmed plots) and $P$. densiflora $(2.87 \pm 0.16$ in the control plots and 3.50 \pm 0.15 in the warmed plots; Table 2).

$R_{\mathrm{S}}$ ( $\mu \mathrm{mol} \mathrm{CO}_{2} \mathrm{~m}^{-2} \mathrm{~s}^{-1}$ ) exhibited seasonal variation ranging from 2.1 to 7.8 in the control plots and from 1.6 to 11.1 in the warmed plots at the $Q$. variabilis plot, and from 1.9 to 6.2 in the control plots and from 2.2 to 7.0 in the warmed plots at the $P$. densiflora plot throughout the growing season (Fig. 3b, c). Mean $R_{\mathrm{S}}$ increased from early in the growing season, reached its peak in August, and gradually decreased from September to November at both the $Q$. variabilis and $P$. densiflora plots.

Figure 4 presents the seasonal variation in the difference in $R_{\mathrm{S}}$ between the control and warmed plots, as well as the increase plots in 2011 and 2012. Black and gray lines indicate the control and warmed plots, respectively. Dashed lines show the differences in air and soil temperatures, soil water content, and $\mathrm{SCO}_{2}$ between the control and warmed plots. The gray bars in $\mathbf{d}$ and $\mathbf{e}$ indicate missing $\mathrm{SCO}_{2}$ data

ratio of $R_{\mathrm{S}}$ normalized by $1{ }^{\circ} \mathrm{C}$ soil warming in the study plots. At the $Q$. variabilis plot, the warming effect on $R_{\mathrm{S}}$ gradually increased from June and peaked in August, while the warming effects on $R_{\mathrm{S}}$ at the $P$. densiflora plot peaked in June and subsequently decreased thereafter. For both species, the differences in $R_{\mathrm{S}}$ were negative in September, and then became positive again in October and November. Positive effects of warming on $R_{\mathrm{S}}$ were generally observed across the seasons for both species. However, a negative effect of warming on $R_{\mathrm{S}}$ was observed at the $P$. densiflora plot in September (Figs. 3c, 4).

\subsection{Relationships between $\boldsymbol{R}_{\mathrm{S}}$ and soil temperature, and soil moisture content}

$R_{\mathrm{S}}$ was correlated with soil temperature in the control and warmed plots for both species $(P<0.001$; Table 3$)$. The annual 


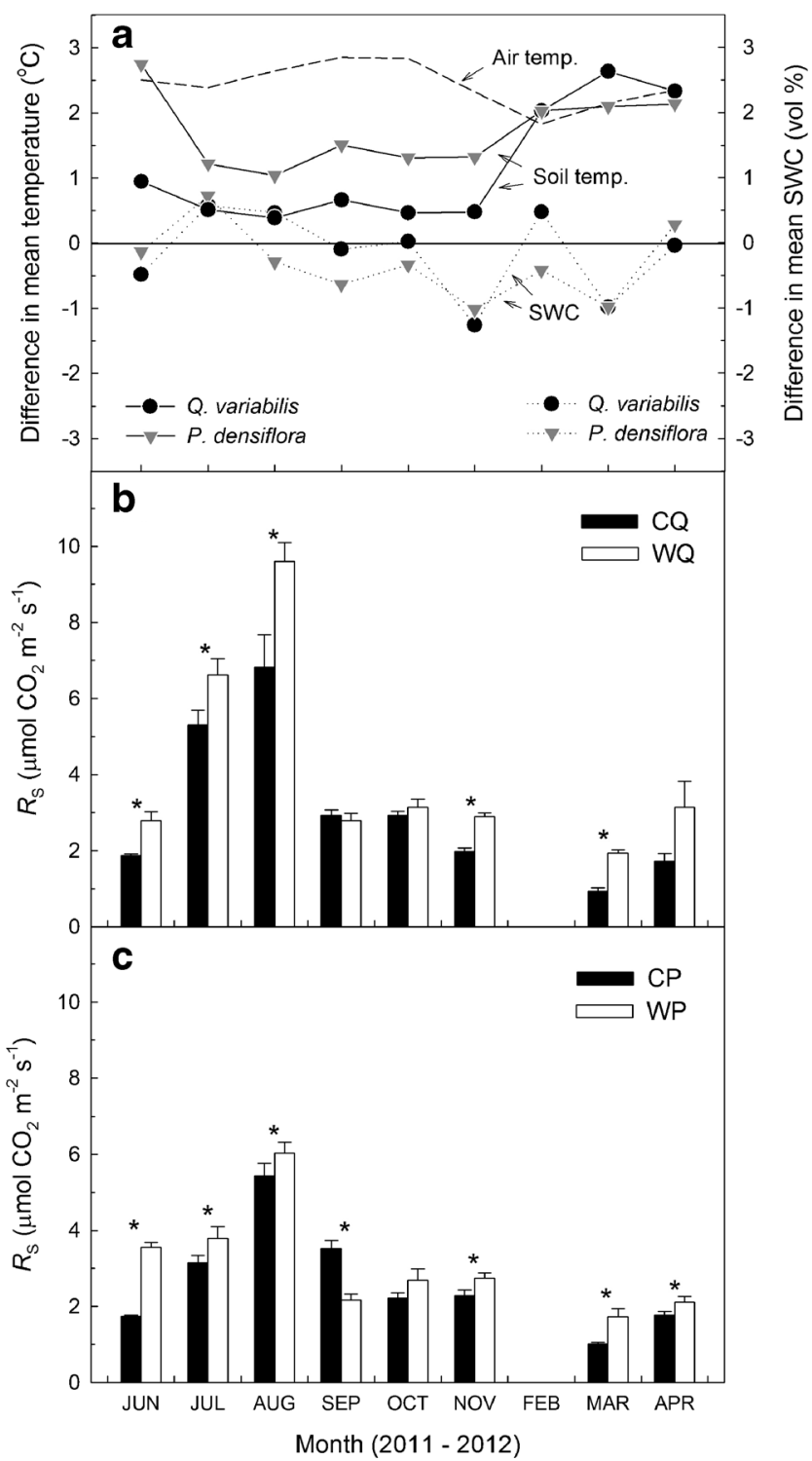

Fig. 3 Seasonal variation in a differences in the mean air (dashed line) and soil temperature (solid line), and volumetric soil water content (dotted line) between the control and warmed plots at the $Q$. variabilis (black) and $P$. densiflora (gray) plots and mean soil $\mathrm{CO}_{2}$ efflux in the control and warmed plots at the $\mathbf{b} Q$. variabilis and $\mathbf{c} P$. densiflora plots from June 2011 to April 2012. Vertical bars indicate the mean $\pm 1 \operatorname{SE}(n=4)$ and the asterisks denote significant differences at the $P=0.05$ level. $C Q$ (control $Q$. variabilis plot), $W Q$ (warmed $Q$. variabilis plot), $C P$ (control $P$. densiflora plot), WP (warmed $P$. densiflora plot)

temperature sensitivity of $R_{\mathrm{S}}$ was higher at the $Q$. variabilis plot than at the $P$. densiflora plot $(P<0.05)$, but was not affected by warming. The $Q_{10}$ values calculated from all the measurements were 2.82 for the control plots and 2.46 for the warmed plots at the $Q$. variabilis plots, and 1.98 for the control plots and 1.81 for the warmed plots at the $P$. densiflora plots (Table 3 ). $R_{\mathrm{S}}$ was positively correlated with soil water content for both $Q$. variabilis plots $\left(R^{2}=0.61, P=0.003\right)$ and P. densiflora plots $\left(R^{2}=0.37, P=0.013\right)$ in 2011 (Fig. 5a). In addition, the effect of warming on $R_{\mathrm{S}}$ was positively correlated

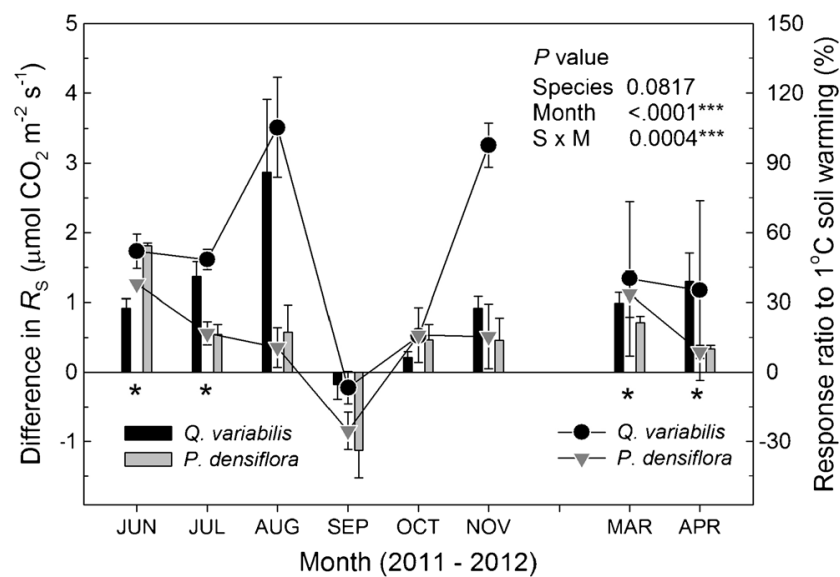

Fig. 4 Difference in soil $\mathrm{CO}_{2}$ efflux $\left(R_{\mathrm{S}}\right)$ between the control and warmed plots (bars) and the response ratio $\left(\%\right.$, points) of $R_{\mathrm{S}}$ to warming between the control and warmed plots from June 2011 to April 2012 at the Q. variabilis (black) and P. densiflora (gray) plots. Values represent the mean $\pm 1 \mathrm{SE}(n=4)$. Results from a two-way ANOVA factoring in species and months are reported in the figure. Asterisks denote significant differences $\left({ }^{*} P<0.05,{ }^{* * *} P<0.001\right)$

with soil water content across all the plots $\left(R^{2}=0.48\right.$, $P=0.013$; Fig. 5b), enabling the identification of the negative effects of warming on $R_{\mathrm{S}}$ at low soil water levels at the P. densiflora plots.

\subsection{Response of soil-air $\mathrm{CO}_{2}$ concentration to warming}

Warming did not affect mean $\mathrm{SCO}_{2}$ for both species; however, significant differences between the two species were observed (Table 1). Mean $\mathrm{SCO}_{2}\left(\mu \mathrm{mol} \mathrm{mol}{ }^{-1}\right)$ demonstrated seasonal variations, ranging from 907 to 12,297 in the control plots and from 1082 to 12,397 in the warmed plots for $Q$. variabilis, and from 888 to 11,383 in the control plots and from 937 to 10,381 in the warmed plots for P. densiflora (Fig. $2 \mathrm{~d}$, e). $\mathrm{SCO}_{2}$ notably fluctuated during the growing season, especially during the periods with rain events.

Figure 6 illustrates one of the clearest diurnal variations of $\mathrm{SCO}_{2}$ with soil temperature, soil water content, and rainfall during a representative period (3 days) of the growing season. Generally, soil temperature and $\mathrm{SCO}_{2}$ exhibited sinusoidal variation. $\mathrm{SCO}_{2}$ dramatically increased with increasing soil water content caused by rainfall, following a time lag. At the same time, significant warming effects on $\mathrm{SCO}_{2}$ were observed at both species (Fig. 6c, d). For instance, the daily mean $\mathrm{SCO}_{2}$ on 29 September was $89 \%$ higher in the warmed plots than in the control plots for Q. variabilis, and $55 \%$ higher in the warmed plots than in the control plots for P. densiflora $(P<0.05)$. In general, soil temperature increased from 6:00, reached its maximum between 15:00 and 16:00, and gradually decreased thereafter, while $\mathrm{SCO}_{2}$ reached a minimum during the daytime in both the control and warmed plots (Fig. 6c, d). 
Table 3 The temperature sensitivity of $R_{\mathrm{S}}$ derived from the relationship between soil temperature and soil respiration $\left(R_{\mathrm{S}}=a \exp ^{b T}\right)$ in the control and warmed plots. $a$, basal respiration rate; $b$, coefficient values for the calculation of the $Q_{10}$ values $\left(Q_{10}=\exp ^{10 b}\right)$. Means $\pm 1 \mathrm{SE}(n=4)$ within a row that differ in their letters are significantly different at $P<0.05$

\begin{tabular}{lllll}
\hline Species & \multicolumn{2}{l}{ Q. variabilis } & & \multicolumn{2}{l}{ P. densiflora } \\
\cline { 2 - 3 } Treatment & Control & Warmed & Control & Warmed \\
\hline$a$ & $0.440 \pm 0.034 \mathrm{~B}$ & $0.710 \pm 0.082 \mathrm{AB}$ & $0.725 \pm 0.060 \mathrm{AB}$ & $0.925 \pm 0.085 \mathrm{~A}$ \\
$b$ & $0.105 \pm 0.003 \mathrm{~A}$ & $0.090 \pm 0.007 \mathrm{~A}$ & $0.068 \pm 0.006 \mathrm{~B}$ & $0.060 \pm 0.004 \mathrm{~B}$ \\
$Q_{10}$ & $2.823 \pm 0.083 \mathrm{~A}$ & $2.455 \pm 0.007 \mathrm{~A}$ & $1.975 \pm 0.103 \mathrm{~B}$ & 0.925 \\
$R^{2}$ & 0.828 & 0.903 & 0.643 & $<0.001$ \\
$P$ & $<0.001$ & $<0.001$ & $<0.001$ & \\
\hline
\end{tabular}

\subsection{Plant biomass}

Warming did not affect plant biomass significantly, while species type, year, and their interaction affected root and shoot biomass (Table 1). At the $Q$. variabilis plots, no significant difference in root and shoot biomass was observed between the control and warmed plots $(P>0.05)$, whereas at the

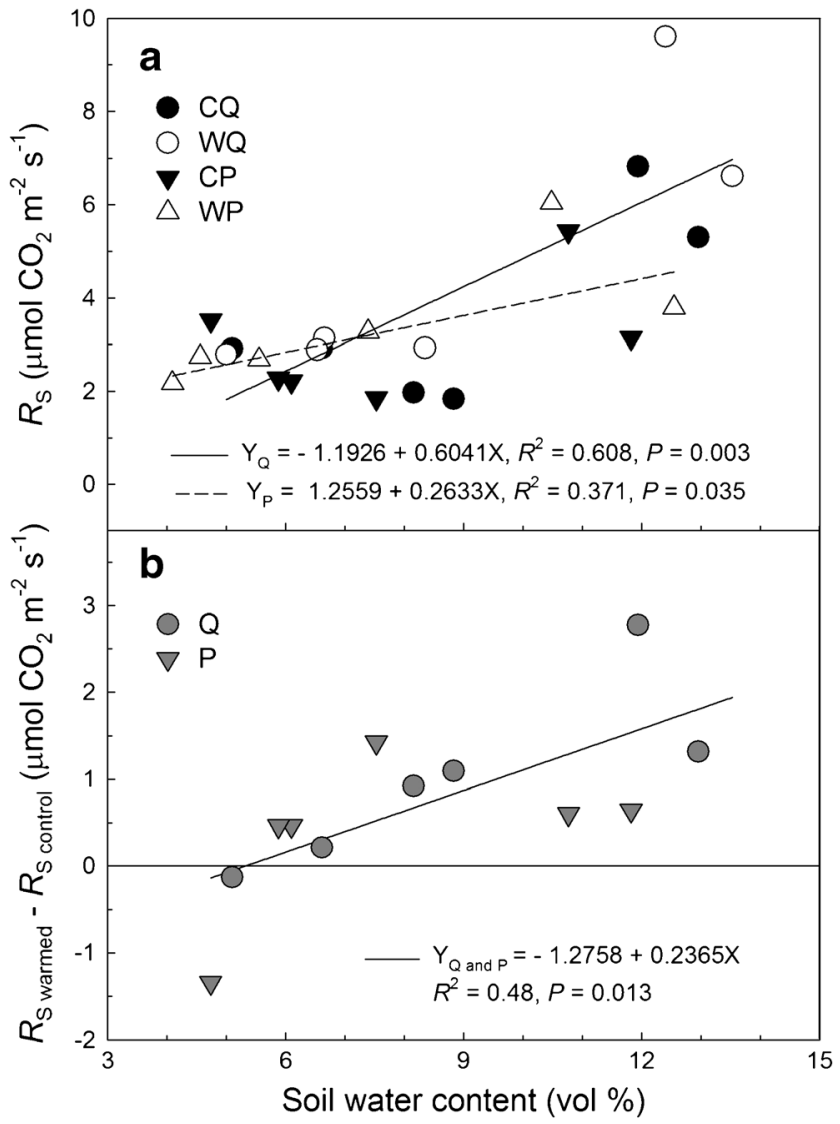

Fig. 5 Plots of a soil $\mathrm{CO}_{2}$ efflux $\left(R_{\mathrm{S}}\right)$ against soil water content and $\mathbf{b}$ the difference in $R_{\mathrm{S}}$ between the control and warmed plots against soil water content for $Q$. variabilis $(Q)$ and $P$. densiflora $(P)$ species in 2011 . These mean values are as in Figs. 3 and 4. The linear regressions were fitted to the data of the each species for $\mathbf{a}$ and all the data of the two species for $\mathbf{b}$. $C Q$ (control $Q$. variabilis plot), $W Q$ (warmed $Q$. variabilis plot), $C P$ (control P. densiflora plot), WP (warmed P. densiflora plot)
P. densiflora plots a trend towards decreased root biomass was observed in the warmed plots relative to the control plots only in 2011 ( $P=0.059$; Table 2$)$. The root biomass was higher at the $Q$. variabilis plots than at the $P$. densiflora plots $(P<0.001)$. In 2011, total biomass values (shoot plus root) for the control and warmed plots were $1.38 \mathrm{~kg} \mathrm{~m}^{-2}$ and $1.75 \mathrm{~kg} \mathrm{~m}^{-2}$ for $Q$. variabilis and 0.50 and $0.42 \mathrm{~kg} \mathrm{~m}^{-2}$ for $P$. densiflora, respectively. Mean $R_{\mathrm{S}}$ increased with increase in root biomass $\left(R^{2}=0.69\right)$ and total biomass $\left(R^{2}=0.73\right)$. But the correlations across both species were not significant due to the limited amount of data $(P>0.05)$. Mean $\mathrm{SCO}_{2}$ was positively correlated with root biomass (Fig. $7 \mathrm{c}, R^{2}=0.99, P=0.003$ ) and total biomass (Fig. $7 \mathrm{~d}, R^{2}=0.87, P=0.007$ ) for both species in 2012.

\section{Discussion}

\subsection{Stronger response of $\boldsymbol{R}_{\mathrm{S}}$ to warming for $\boldsymbol{Q}$. variabilis than for $P$. densiflora}

In this study, warming stimulated the mean $R_{\mathrm{S}}$ rate by 29 and $22 \%$ at the $Q$. variabilis and $P$. densiflora plots, respectively (Table 2). These response ratios were higher than the normalized mean response ratio (12\%) of $R_{\mathrm{S}}$ derived from experimental warming of $2{ }^{\circ} \mathrm{C}$ in temperate forests (Wang et al. 2014), supporting the observation that young tree seedlings in early development stages are more responsive to increasing temperature than are mature or old growth stands (Xu et al. 2012).

We hypothesized that the $R_{\mathrm{S}}$ response to a temperature rise with $Q$. variabilis seedlings would be stronger than with $P$. densiflora seedlings. Our study showed that the average effect of warming on $R_{\mathrm{S}}$ was higher at the $Q$. variabilis plot than at the $P$. densiflora plot, despite the warming effect on soil temperature being lower than for $P$. densiflora. Also, there was no significant increase in plant biomass for either species. The lower warming effect on $P$. densiflora seedlings may be related to the lower dependency of $R_{\mathrm{S}}$ to growth temperature than 

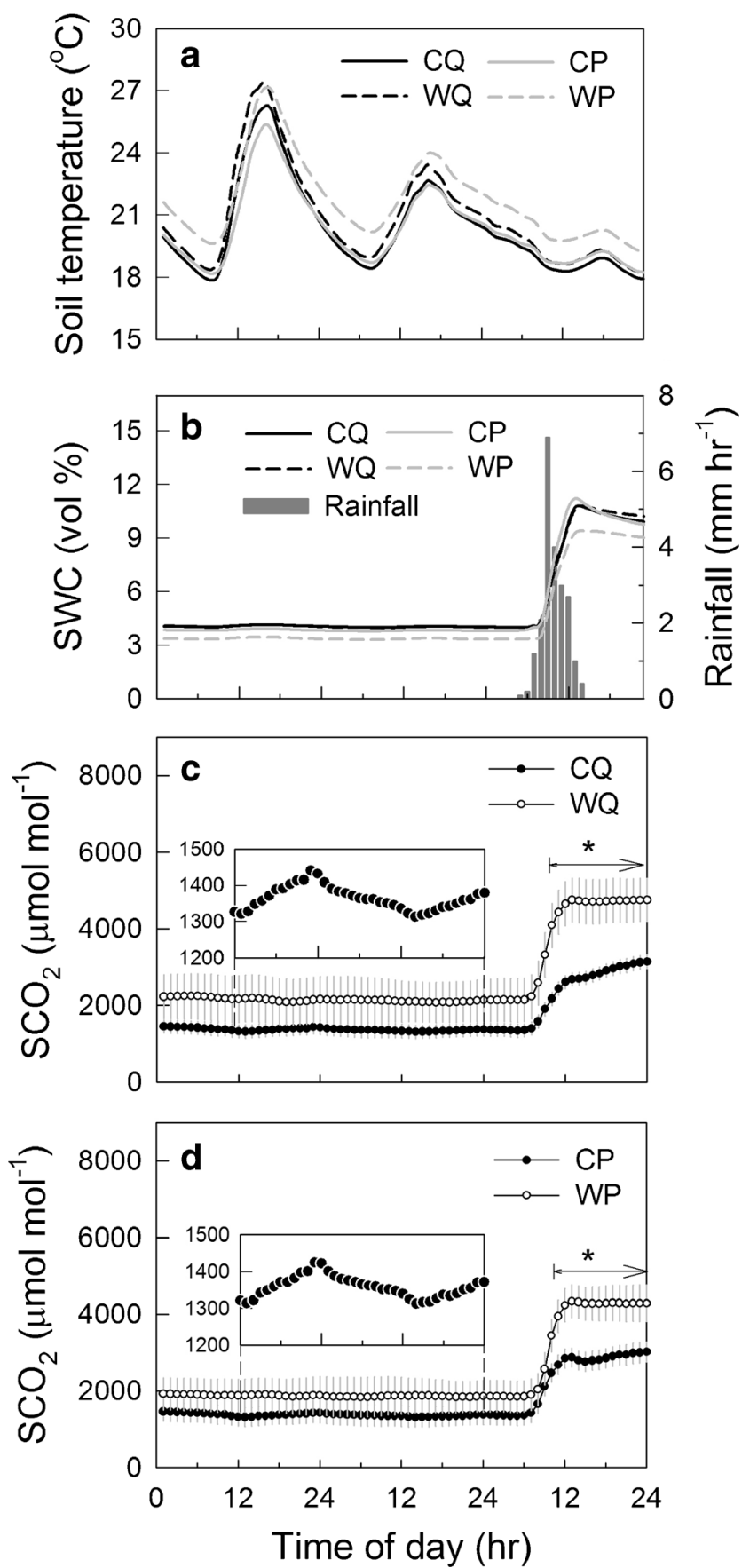

Fig. 6 Diurnal variations of hourly mean a soil temperature; b volumetric soil water content and rainfall and soil-air $\mathrm{CO}_{2}$ concentration at the $\mathbf{c} Q$. variabilis and $\mathbf{d}$ P. densiflora sites (27-29 September 2011). $C Q$ (control $Q$. variabilis plot), $W Q$ (warmed $Q$. variabilis plot), $C P$ (control $P$. densiflora plot), WP (warmed $P$. densiflora plot). The closed and open circles indicate the control and warmed plots, respectively. Each value is the hourly mean $\pm 1 \mathrm{SE}(n=4)$. The insets in $\mathbf{c}$ and $\mathbf{d}$ present the $y$-axis on a finer scale before rainfall and the asterisks denote significant differences in $\mathrm{SCO}_{2}$ between the control and warmed plots $(P<0.05)$

Q. variabilis seedlings (Table 3). Way and Oren (2010) addressed why evergreen trees may be less responsive to growth temperature. The adaptation strategies of evergreen trees are generally suited to resource-poor environments and thus evergreens have more conservative responses to changing environmental conditions, such as their trade-offs between nutrient retention and plant growth (Givnish 2002; Aerts 1995). At our Q. variabilis plot, the warming-induced $R_{\mathrm{S}}$ may have been affected by an increase in photosynthesis capacity, such as increases in leaf longevity (Han et al. 2014a), chlorophyll content, and photosynthesis rate (Jo et al. 2011) in the same year, even though biomass was not significantly changed by warming. In addition, the $1.1{ }^{\circ} \mathrm{C}$ increase in soil temperature could directly stimulate rhizospheric respiration. On the other hand, at the $P$. densiflora plot, the warming did not affect any physiological leaf traits such as leaf nitrogen concentration or chlorophyll content (Lee et al. 2013). If the warming decreased root respiration in association with a negative plant productivity response to warming ( $\mathrm{Li}$ et al. 2013), the warming-induced increase in $R_{\mathrm{S}}$ may have resulted mainly from the increase in rhizospheric and heterotrophic respiration by $2.4{ }^{\circ} \mathrm{C}$ soil warming (Kuzyakov and Gavrichkova 2010). If warming increased root respiration without increase in plant biomass, these results could be explained by differences in $\mathrm{C}$ allocation strategies between plant growth and respiration in warming conditions and different temperature dependencies. In other words, increases in respiration and photosynthetic capacity do not necessarily lead to more plant growth if the $\mathrm{C}$ allocation was used by the plants more for respiration than growth. This study cannot explain further due to a lack of data. However, more studies comparing the potential changes in the carbon allocation strategies, stomatal conductances and other C-demanding processes such as root exudation, of different species will give us clear insight and a better understanding of the links aboveground and belowground $\mathrm{C}$ processes.

\subsection{Different seasonal variations in warming effects on $\boldsymbol{R}_{\mathrm{S}}$ between the two species}

We found differences in the temporal variation of the warming effect between $Q$. variabilis and P. densiflora (Fig. 4). The different warming effects on $R_{\mathrm{S}}$ could be explained by species-specific temperature sensitivities reflecting differences in leaf phenology between deciduous and coniferous seedlings (Curiel Yuste et al. 2004). The annual $Q_{10}$ value of $R_{\mathrm{S}}$ reflecting a temperature dependency to seasonal soil temperature was also significantly higher in the $Q$. variabilis plot than in the P. densiflora plot (Table 3). The effect of warming was mainly noticeable in August at the $Q$. variabilis site whereas in June at the $P$. densiflora site. Because the leaf unfolding stage for $Q$. variabilis seedlings continued until the end of May with a leaf chlorophyll content peak in July (Jo et al. 2011; Han et al. 2014a), this may have led to the 
Fig. 7 Relationships between mean $\mathrm{SCO}_{2}$ and root and total biomass (shoot + root) across both tree species in a, b 2011 and c, d 2012. $C Q$ (control Q. variabilis plot), $W Q$ (warmed $Q$. variabilis plot), $C P$ (control $P$. densiflora plot), WP (warmed $P$. densiflora plot). The values indicate mean $\pm 1 \mathrm{SE}(n=4)$
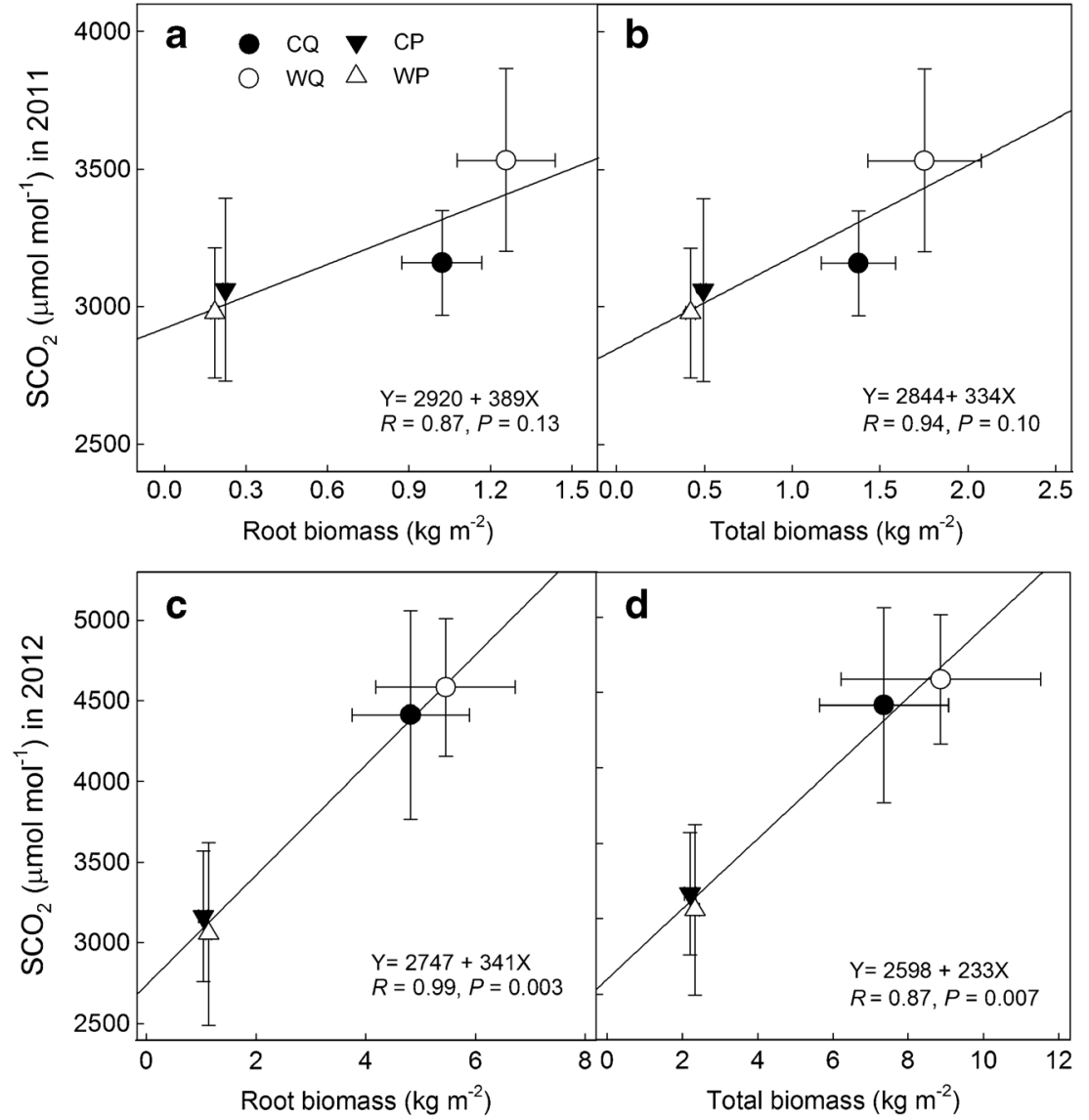

pronounced warming effect appearing later for $Q$. variabilis than for $P$. densiflora. Since root respiration, as a component of $R_{\mathrm{S}}$, originates from leaf photosynthesis, the effect of warming on $R_{\mathrm{S}}$ for $Q$. variabilis seedlings may depend on leaf emergence and leaf area expansion (Du and Fang 2014). At this study site, warming increased leaf longevity in Q. variabilis seedlings by 27 days (Han et al. 2014a). In contrast, $P$. densiflora seedlings demonstrated no distinct leaf flushing and less variation in leaf chlorophyll content than did Q. variabilis seedlings from May to July (Lee et al. 2013). Therefore, the stronger effect of warming observed in $P$. densiflora seedlings during the early growing season may be due to the earlier $\mathrm{C}$ transition from needles to roots.

\subsection{Soil water contents and the warming effect on $\boldsymbol{R}_{\mathrm{S}}$}

We found a positive correlation between warming effects and soil moisture contents (Fig. 5b) suggesting that a severe drought before or after a rainy season might alter the warming effect. At our nursery site with sandy soil, the soil water contents were very low at the lower end of general soil water content range. Davidson et al. (1998) revealed a bimodal relation between $R_{\mathrm{S}}$ and volumetric water content in a temperate mixed hardwood forest, showing a positive correlation with a steep slope during the peak of the drought in August and
September. However, the dependency of $R_{\mathrm{S}}$ on soil water content that has been identified across studies is inconsistent due to complex mechanisms that are involved in moisture regulations of $\mathrm{CO}_{2}$ production and transport processes (Luo and Zhou 2006), nursery warming experiments with wider ranges in soil water content should be considered. A recent study by Jarvi and Burton (2013) reported that soil warming increased root respiration rates when soil moisture was enhanced by the addition of water through rainfall. In our study, the mean soil water content during $R_{\mathrm{S}}$ measurement in September was down to $4 \mathrm{vol} \%$ (Fig. $2 \mathrm{c}$ ) and the negative effect on $R_{\mathrm{S}}$ was less pronounced at the $Q$. variabilis plot than at the $P$. densiflora plot. If the negative effect on $R_{\mathrm{S}}$ is attributed to a reduction in plant growth associated with warminginduced drought, the $Q$. variabilis seedlings might be more water-stress tolerant than $P$. densiflora seedlings (Schwanz and Polle 2001). After rainfall, the positive effect of warming on $R_{\mathrm{S}}$ in the seedlings of both species was observed in October and November (Fig. 4). Because prolonged drought decreases heterotrophic respiration and photosynthetic capacity, warming-induced severe drought might offset the effect of increasing temperature on $R_{\mathrm{S}}$ (Borken et al. 2006; Misson et al. 2010; Xu and Baldocchi 2003). Therefore, further studies on the response of $R_{\mathrm{S}}$ to long-term warming combined with precipitation manipulation are needed. 


\subsection{Responses of plant biomass and $\mathrm{SCO}_{2}$ to warming}

In this study, warming did not significantly increase the biomass of $Q$. variabilis seedlings ( $27 \%, P=0.367)$. Intraspecific competition during shoot growth among $Q$. variabilis seedlings may cause large variations in biomass within a single plot. A meta-analysis by Lin et al. (2010) reported that warming generally increased both above and belowground biomass of woody plants by $26.7 \%$, although these changes depended on tree species, the level of warming, and the experimental period. According to Way and Oren (2010), the growth of deciduous trees is more responsive to increasing temperatures than that of evergreen trees. Specifically, the average response of growth variables (e.g., shoot height, stem diameter, and biomass) to a $3.4^{\circ} \mathrm{C}$ increase in growth temperature was positive for deciduous trees and negative for evergreen trees. However, more species should be considered when determining the response of broader functional types to warming (Fisichelli et al. 2014; Han et al. 2014b). In our study, a trend towards slightly decreased root biomass was observed in the warmed plot of $P$. densiflora seedlings in $2011(17 \%, P=0.059$; Table 2$)$. Decrease in growth rate or the change in $\mathrm{C}$ allocation can occur when warming-induced increases in respiration rate are greater than that in $\mathrm{C}$ assimilation rate due to photosynthesis (Kramer et al. 2000). Similar responses were also observed in the effect of warming on $\mathrm{SCO}_{2}$. No significant difference in mean $\mathrm{SCO}_{2}$ between the control and warmed plots was identified. However, we found a positive correlation between plant biomass and mean $\mathrm{SCO}_{2}$ across the control and warmed plots of the two species (Fig. $7 \mathrm{c}, \mathrm{d}$ ). These results suggest that $\mathrm{SCO}_{2}$ concentration could be a useful indicator of the release of $\mathrm{C}$ from the rhizosphere when significant changes in plant production due to warming would be expected. The $\mathrm{SCO}_{2}$ concentration fluctuated markedly in comparison to previous studies (e.g., Tang et al. 2003; Yonemura et al. 2013). In particular, $\mathrm{SCO}_{2}$ demonstrated a sensitive response to rainfall on diurnal time scales (Fig. 6). This may reflect the rapid water dispersion in the sandy soil. On the other hand, significant differences in $\mathrm{SCO}_{2}$ between the control and warmed plots were observed after rainfall, following a time lag (Fig. 6c, d). Therefore, further studies are required to determine $\mathrm{SCO}_{2}$ sensitivity to air-filled porosity and associated gas diffusion rates, as well as the effects of the soil depth at which sensors are located on the measurement of $\mathrm{SCO}_{2}$.

\section{Conclusions}

Warming significantly increased mean $R_{\mathrm{S}}$ in both $Q$. variabilis and $P$. densiflora plots, but did not influence plant biomass in either species. Warming-induced increase in $R_{\mathrm{S}}$ did not seem to be directly linked to plant biomass, but the positive correlation between biomass and $\mathrm{SCO}_{2}$ in the wide range of the plant biomass of the two species shows that $\mathrm{SCO}_{2}$ may be useful index to access the warming effect on plant growth when its remarkable changes would be observed. In addition, $R_{\mathrm{S}}$ was more responsive to warming for $Q$. variabilis seedlings than for $P$. densiflora seedlings. If this result could be repeated at multiple developmental stages in future research, such different responses would imply that, in a warmer climate in Korean forests, $Q$. variabilis would accelerate its belowground $\mathrm{C}$ turnover more than $P$. densiflora. The warming effects on $R_{\mathrm{S}}$ also varied seasonally for both species showing that drier soil conditions would lead to a less or negative response of $R_{\mathrm{S}}$ to increasing temperature. This study shows that differences in seasonal variation in the response of $R_{\mathrm{S}}$ to temperature rises reflect differences in leaf phenology between deciduous and evergreen trees. This field-based evidence would contribute to accurate future predictions of the soil $\mathrm{C}$ cycle under climate change.

Acknowledgments We would like to thank students of Ecosystem Ecology laboratory for their experimental assistance. We thank the editors and two anonymous reviewers who commented on the manuscript.

\section{Compliance with ethical standards}

Funding This study was supported by National Research Foundation of Korea (2010-0014620), Korea Forest Service (S111112L030100).

\section{References}

Aerts R (1995) The advantages of being evergreen. Trends Ecol Evol 10: 402-407. doi:10.1016/S0169-5347(00)89156-9

Atkin OK, Edwards EJ, Loveys BR (2000) Response of root respiration to changes in temperature and its relevance to global warming. New Phytol 147:141-154. doi:10.1046/j.1469-8137.2000.00683.x

Bekku Y, Koizumi H, Nakadai T, Iwaki H (1995) Measurement of soil respiration using closed chamber method: an IRGA technique. Ecol Res 10:369-373. doi:10.1007/BF02347863

Borken W, Savage K, Davidson EA, Trumbore SE (2006) Effects of experimental drought on soil respiration and radiocarbon efflux from a temperate forest soil. Glob Chang Biol 12:177-193. doi:10. 1111/j.1365-2486.2005.001058.x

Bradford MA, Davies CA, Frey SD, Maddox TR, Melillo JM, Mohan JE, Reynolds JF, Treseder KK, Wallenstein MD (2008) Thermal adaptation of soil microbial respiration to elevated temperature. Ecol Lett 11:1316-1327. doi:10.1111/j.1461-0248.2008.01251.x

Byun JG, Lee WK, Kim M, Kwak DA, Kwak H, Park T, Byun WH, Son Y, Choi JK, Lee YJ, Saborowski J, Chung DJ, Jung JH (2013) Radial growth response of Pinus densiflora and Quercus spp. to topographic and climatic factors in South Korea. J Plant Ecol 6: 380-392. doi:10.1093/jpe/rtt001

Chung H, Muraoka H, Nakamura M, Han S, Muller O, Son Y (2013) Experimental warming studies on tree species and forest ecosystems: a literature review. J Plant Res 126:447-460. doi:10.1007/ s10265-013-0565-3 
Contosta AR, Frey SD, Cooper AB (2011) Seasonal dynamics of soil respiration and $\mathrm{N}$ mineralization in chronically warmed and fertilized soil. Ecosphere 2:art36. doi:10.1890/ES10-00133.1

Curiel Yuste J, Janssens IA, Carrara A, Ceulemans R (2004) Annual Q 10 of soil respiration reflects plant phenological patterns as well as temperature sensitivity. Glob Chang Biol 10:161-169. doi:10. $1111 / j .1529-8817.2003 .00727 . x$

Danyagri G, Dang QL (2014) Effects of elevated $\left[\mathrm{CO}_{2}\right]$ and soil temperature on photosynthetic responses of maple (Acer spicatum L.) seedlings to light. Environ Exp Bot 107:64-70. doi:10.1016/j. envexpbot.2014.05.010

Davidson EA, Belk E, Boone RD (1998) Soil water content and temperature as independent confounded factors controlling soil respiration in a temperature mixed hardwood forest. Glob Chang Biol 4:217-227

Du E, Fang J (2014) Linking belowground and aboveground phenology in two boreal forests in Northeast China. Oecologia 176:883-892. doi:10.1007/s00442-014-3055-y

Fisichelli N, Wright A, Rice K, Mau A, Buschena C, Reich PB (2014) First-year seedlings and climate change: species-specific responses of 15 North American tree species. Oikos 123:1331-1340. doi:10. 1111/oik.01349

Flanagan LB, Sharp EJ, Letts MG (2013) Response of plant biomass and soil respiration to experimental warming and precipitation manipulation in a Northern Great Plains grassland. Agric For Meteorol 173: 40-52. doi:10.1016/j.agrformet.2013.01.002

Givnish TJ (2002) The adaptive significance of evergreen vs. deciduous leaves: solving the triple paradox. Silva Fenn 36:703-743

Hamann A, Wang T (2006) Potential effects of climate change on ecosystem and tree species distribution in British Columbia. Ecology 87:2773-2786. doi:10.1890/0012-9658(2006)87[2773:PEOCCO] 2.0.CO;2

Han S, Chung H, Noh NJ, Lee SJ, Jo W, Yoon TK, Yi K, Park C, Ko S, Son Y (2014a) Effect of open-field experimental warming on the leaf phenology of Q. variabilis (Quercus variabilis) seedlings. J Plant Ecol 7:559-566. doi:10.1093/jpe/rtt067

Han S, An J, Yoon TK, Yun SJ, Hwang J, Cho MS, Son Y (2014b) Species-specific growth responses of Betula costata, Fraxinus rhynchophylla, and Quercus variabilis seedlings to open-field artificial warming. Kor J Agric For Meteorol 16:219-226. doi:10.5532/ KJAFM.2014.16.3.219

Inoue T, Nagai S, Inoue S, Ozaki M, Sakai S, Muraoka H, Koizumi H (2012) Seasonal variability of soil respiration in multiple ecosystems under the same physical-geographical environmental conditions in central Japan. For Sci Technol 8:52-60. doi:10.1080/21580103. 2012.672012

IPCC (2013) Climate change 2013: the physical science basis. In: Stocker TF, Qin D, Plattner G-K, Tignor M, Allen SK, Boschung J, Nauels A, Xia Y, Bex V, Midgley PM (eds) Contribution of working group I to the fifth assessment report of the intergovernmental panel on climate change. Cambridge University Press, Cambridge, pp 1029-1136

Jarvi MP, Burton AJ (2013) Acclimation and soil moisture constrain sugar maple respiration in experimentally warmed soil. Tree Physiol 33:949-959. doi:10.1093/treephys/tpt068

Jo W, Son Y, Chung H, Noh NJ, Yoon TK, Han S, Lee SJ, Lee SK, Yi K, Jin L (2011) Effect of artificial warming on chlorophyll contents and net photosynthetic rate of Quercus variabilis seedlings in an openfield experiment. J Korean For Soc 100:733-737 (in Korean with English abstract)

Kaye MW, Wagner RJ (2014) Eastern deciduous tree seedlings advance spring phenology in response to experimental warming, but not wetting, treatments. Plant Ecol 215:543-554. doi:10.1007/s11258014-0322-2

Khaine I, Woo SY (2015) An overview of interrelationship between climate change and forests. For Sci Technol 11:11-18. doi:10. 1080/21580103.2014.932718
Kimball BA, Conley MM, Wang S, Lin X, Luo C, Morgan J, Smith D (2008) Infrared heater arrays for warming ecosystem field plots. Glob Chang Biol 14:309-320. doi:10.1111/j.1365-2486.2007. 01486.x

Korea Forest Service (2014) Statistical yearbook of forestry. Daejeon, Korea (in Korean)

Korea Meteorological Administration (2015) Statistical database. http:// www.kma.go.kr/

Korea Meteorological Administration (2012) Korea climate change report. KMA, Seoul, http://www.climate.go.kr/home/cc_data/2013/ korea climate/13-0311 korea climate.pdf

Kramer J, Keinonen I, Loustau D (2000) The importance of phenology for the evaluation of impact of climate change on growth of boreal, temperate and Mediterranean forests ecosystems: an overview. Int J Biometeorol 44:67-75. doi:10.1007/s004840000066

Kuzyakov Y, Gavrichkova O (2010) Time lag between photosynthesis and carbon dioxide efflux from soil: a review of mechanisms and controls. Glob Chang Biol 16:3386-3406. doi:10.1111/j.1365-2486. 2010.02179.x

Kwak DA, Lee WK, Son Y, Choi S, Yoo S, Chung DJ, Lee SH, Kim SH, Choi JK, Lee YJ, Byun WH (2012) Predicting distributional change of forest cover and volume in future climate of South Korea. For Sci Technol 8:105-115. doi:10.1080/21580103.2012.673751

Lee SW, Kim JW, Kim WG, Jo MS (2009) Silvicultural technique for Korean major species. Korea For Res Inst (in Korean)

Lee SJ, Han S, Yoon TK, Chung H, Noh NJ, Jo W, Park C, Ko S, Han SH, Son Y (2012) Effects of experimental warming on growth of Quercus variabilis seedlings. J Korean For Soc 101:722-728 (in Korean with English abstract)

Lee SJ, Han S, Yoon TK, Han SH, Jung Y, Yun SJ, Son Y (2013) Growth and physiological characteristic of Pinus densiflora seedlings in response to open-field experimental warming using the infrared lamp. J Korean For Soc 102:522-529 (in Korean with English abstract)

Li N, Wang G, Yang Y, Gao Y, Liu G (2011) Plant production, and carbon and nitrogen source pools are strongly intensified by experimental warming in alpine ecosystems in the Qinghai-Tibet Plateau. Soil Biol Biochem 43:942-953. doi:10.1016/j.soilbio.2011.01.009

Li D, Zhou X, Wu L, Zhou J, Luo Y (2013) Contrasting responses of heterotrophic and autotrophic respiration to experimental warming in a winter annual-dominated prairie. Glob Chang Biol 19:35533564. doi:10.1111/gcb.12273

Lin D, Xia J, Wan S (2010) Climate warming and biomass accumulation of terrestrial plants: a meta-analysis. New Phytol 188:187-198. doi: 10.1111/j.1469-8137.2010.03347.x

Liu Q, Yin H, Chen J, Zhao C, Cheng X, Wei Y, Lin B (2011) Belowground responses of Picea asperata seedlings to warming and nitrogen fertilization in the eastern Tibetan Plateau. Ecol Res 26:637-648. doi:10.1007/s11284-011-0824-5

Lu M, Zhou X, Yang Q, Li H, Luo Y, Fang C, Chen J, Yang X, Li B (2013) Responses of ecosystem carbon cycle to experimental warming: a meta-analysis. Ecology 94:726-738. doi:10.1890/120279.1

Luo Y, Zhou X (2006) Soil respiration and the environment. Academic Press, Elsevier

Maier M, Schack-Kirchner H (2014) Using the gradient method to determine soil gas flux: a review. agric for meteorol 192-193:78-95. doi: 10.1016/j.agrformet.2014.03.006

Misson L, Limousin J-M, Rodriguez R, Letts MG (2010) Leaf physiological responses to extreme droughts in Mediterranean Quercus ilex forest. Plant Cell Environ 33:1898-1910. doi:10.1111/j.1365-3040. 2010.02193.x

Morin X, Roy J, Sonié L, Chuine I (2010) Changes in leaf phenology of three European oak species in response to experimental climate change. New Phytol 186:900-910. doi:10.1111/j.1469-8137.2010. 03252.x 
Moyano FE, Kutsch WL, Rebmann C (2008) Soil respiration fluxes in relation to photosynthetic activity in broad-leaf and needle-leaf forest stands. Agric For Meteorol 148:135-143. doi:10.1016/j. agrformet.2007.09.006

Pumpanen J, Heinonsalo J, Rasilo T, Villemot J, Ilvesniemi H (2012) The effects of soil and air temperature on $\mathrm{CO}_{2}$ exchange and net biomass accumulation in Norway spruce, Scots pine and silver birch seedlings. Tree Physiol 32:724-736. doi:10.1093/treephys/tps007

Rustad LE (2008) The response of terrestrial ecosystems to global climate change: towards an integrated approach. Sci Total Environ 404:222 235. doi:10.1016/j.scitotenv.2008.04.050

Schlesinger WH, Andrews JA (2000) Soil respiration and the global carbon cycle. Biogeochemistry 48:7-20. doi:10.1023/ A:1006247623877

Schwanz P, Polle A (2001) Differential stress responses of antioxidative systems to drought in pendunculate oak (Quercus robur) and maritime pine (Pinus pinaster) grown under high $\mathrm{CO}_{2}$ concentrations. $\mathrm{J}$ Exp Bot 52:133-143. doi:10.1093/jexbot/52.354.133

Spittlehouse DL, Stewart RB (2003) Adaptation to climate change in forest management. BC J Ecosyst Manage 4:1-11

Sykes MT, Prentice IC (1996) Climate change, tree species distributions and forest dynamics: a case study in the mixed conifer/northern hardwoods zone of northern Europe. Clim Chang 34:161-177. doi:10.1007/BF00224628

Tang J, Baldocchi DD, Qi Y, Xu L (2003) Assessing soil $\mathrm{CO}_{2}$ efflux using continuous measurement of $\mathrm{CO}_{2}$ profiles in soils with small solidstate sensors. Agric For Meteorol 118:207-220. doi:10.1016/S01681923(03)00112-6

Wang X, Liu L, Piao S, Janssens IA, Tang J, Liu W, Chi Y, Wang J, Xu S (2014) Soil respiration under climate warming: differential response of heterotrophic and autotrophic respiration. Glob Chang Biol 20: 3229-3237. doi:10.1111/gcb.12620

Way DA, Oren R (2010) Differential responses to changes in growth temperature between trees from different functional groups and biomes: a review and synthesis of data. Tree Physiol 30:669-688. doi: 10.1093/treephys/tpq015

Xu L, Baldocchi DD (2003) Seasonal trends in photosynthetic parameters and stomatal conductance of blue oak (Quercus douglasii) under prolonged summer drought and high temperature. Tree Physiol 23: 865-877. doi:10.1093/treephys/23.13.865

Xu Z, Yin H, Xiong P, Wan C, Liu Q (2012) Short-term responses of Picea asperata seedlings of different ages grown in two contrasting forest ecosystems to experimental warming. Environ Exp Bot 77:111. doi:10.1016/j.envexpbot.2011.10.011

Yasuda T, Yonemura S, Tani A (2012) Comparison of the characteristics of small commercial NDIR $\mathrm{CO}_{2}$ sensor models and development of a portable $\mathrm{CO}_{2}$ measurement device. Sensors 12:3641-3655. doi:10. $3390 / \mathrm{s} 120303641$

Yin H, Liu Q, Lai T (2008) Warming effects on growth and physiology in the seedlings of the two conifers Picea asperata and Abies faxoniana under two contrasting light conditions. Ecol Res 23: 259-469. doi:10.1007/s11284-007-0404-x

Yin H, Xiao J, Li Y, Chen Z, Cheng X, Zhao C, Liu Q (2013) Warming effects on root morphological and physiological traits: the potential consequences on soil $\mathrm{C}$ dynamics as altered root exudation. Agric For Meteorol 180:287-296. doi:10.1016/j.agrformet.2013.06.016

Yonemura S, Yokozawa M, Sakurai G, Mo W, Lee N, Murayama S, Ishijima K, Shirato Y, Koizumi H (2013) Vertical soil-air $\mathrm{CO}_{2}$ dynamics at the Takayama deciduous broadleaved forest AsiaFlux site. J For Res 18:49-59. doi:10.1007/s10310-012-0385-7 